\title{
The Prevalence of Hearing Loss Among Babies in the Neonatal Intensive Care Unit in a Tertiary Hospital in Malaysia
}

\section{Malezya'daki Üçüncü Basamak Bir Hastaneden Yenidoğan Yoğun Bakım Ünitesindeki Bebekler Arasında İşitme Kaybının Yaygınlığı}

\author{
Asma ABDUlLAH $\odot$, Khairul Azlan Shahril Abu DAHARI $\odot$, Azmi Mohd TAMil $\odot$, Jaafar ROHANA $\odot$, \\ Mohamad Yunus Mohd RAZIF $\odot$, Ishak SHAREENA $\odot$
}

Ethics Committee Approval: This study was approved by the Universiti Kebangsaan Malaysia Medical Centre, Research and Ethic Committee, 15 January 2015, 1.5.3.5/244/FF429.

Conflict of interest: The authors declare that they have no conflict of interest.

Funding: None.

Informed Consent: Informed consent was taken from the patients enrolled in this study.
Cite as: Abdullah A, Dahari KASA, Tamil AM, Rohana J, Razif MYM, Shareena I. The prevalence of hearing loss among babies in the neonatal intensive care unit in a tertiary hospital in Malaysia. Medeniyet Med J. 2020;35:116-20.

\begin{abstract}
Objective: To study the prevalence of hearing loss $(H L)$ and to identify the possible risk factors causing $H L$.

Methods: This retrospective study was conducted from January 2014-December 2016 at a tertiary hospital in Malaysia. All neonates admitted to the neonatal intensive care unit (NICU), Universiti Kebangsaan Malaysia Medical Centre (UKMMC) were screened with a two-step protocol using an automated auditory brain response $(A A B R)$ and/or Otoacoustic Emission and auditory brain response $(A B R)$. Descriptive analysis was used for the prevalence of $H L$, degree of $H L$ and number of risk factors per infant.

Results: A total of 2713 babies underwent hearing screening in NICU was enrolled in this study. Two thousand six hundred eight (96\%) babies passed the screening test and 214 (4\%) babies required further diagnostic test. Only 105 (49\%) babies completed diagnostic tests. Out of 105 babies, 40 (38.1\%) babies had HL. Mild HL was the commonest HL with 22 (55\%), moderate $H L$ was in seven babies (17.5\%), severe HL in two babies (5\%), and profound HL in nine babies (22.5\%). The presence of craniofacial anomalies was the only significant independent risk factor for $\mathrm{HL}$ with $p<0.05$ with an odds ratio of $0.105 \mathrm{Cl} 95 \%$ [0.028-0.389]. Of Babies with the presence of three or more risk factors, $100 \%$ of them had $\mathrm{HL}$.

There was an increased risk of hearing loss in those with craniofacial anomalies up to 11 times higher compared to those without such anomalies.

Conclusion: The prevalence of HL among the NICU babies was $1.5 \%$ and mild HL was the commonest degree of HL (55\%).
\end{abstract}

Keywords: Craniofacial anomalies, hearing loss, intensive care unit, universal hearing screening Öz

Amaç: İşitme kaybı (iK) prevalansını araştırmak ve işitme kaybına neden olabilecek risk faktörlerini saptamaktır.

Yöntem: Bu retrospektif çalışma, Ocak 2014-Aralık 2016 tarihleri arasında Malezya'daki bir üç̈ncü basamak hastanede gerçeklestirilmiștir. Malezya Kebangsaan Üniversitesi Tıp Merkezi yenidoğan yoğun bakım ünitesine kabul edilen tüm yenidoğanlarda, otomatik işitsel beyin yanıtı $(A A B R)$ ve/veya otoakustik emisyon ve işitsel beyin yanıtı $(A B R)$ yöntemleri kullanılarak iki aşamalı bir protokol izlenmiştir. Bebek bassına ișitme kaybı prevalansı, ișitme kaybı derecesi ve risk faktörlerinin sayısı için betimsel analiz kullanılmıştır.

Bulgular: Bu çalışmaya katılan toplam 2713 bebeğe işitme taraması yapılmıştır. Íki bin altı yüz sekiz (\%96) bebek tarama testini geçmistir ve 214 (\%4) bebek için tanılama testine ihtiyaç duyulmuştur. Sadece 105 (\%49) bebek tanılama testini tamamlamıştır. 105 bebeğin 40'ında $(\% 38,1)$ iK bulunmuştur. En sık olarak hafif iK 22 bebekte (\%55) görülürken, yedi bebekte (\%17.5) orta seviyede iK, iki bebekte (\%5) siddetli iK ve dokuz bebekte (\%22.5) ise derin iK belirlenmistir. Kraniyofasiyal anomaliler IK için tek anlamlı bağımsız risk faktörüdür ( $p<0.05)$, olasılık oranı 0.105 GA \%95'tir [0.028-0.389]. Üç veya daha fazla risk faktörü bulunan bebeklerin \%100'ünde iK saptanmistır.

Sonuc: Araştırmaya katılan bebeklerde işitme kaybı prevalansı \%1.5 ve en yaygın IK (\%55) hafif derecede HL olarak belirlenmiştir.

Anahtar kelimeler: Kraniyofasiyal anomaliler, işitme kaybı, yoğun bakım ünitesi, evrensel işitme taraması

(C) Copyright Istanbul Medeniyet University Faculty of Medicine. This journal is published by Logos Medical Publishing.

Licenced by Creative Commons Attribution-NonCommercial 4.0 International (CC BY-NC 4.0)
Received: 1 May 2020

Accepted: 27 May 2020

Online First: 30 June 2020

Corresponding Author:

A. Abdullah

ORCID: 0000-0002-0103-8858

Universiti Kebangsaan

Malaysia Medical Centre,

Department of Otorhinolaryngology-

Head and Neck Surgery,

Kuala Lumpur, Malaysia

asmappukm@gmail.com

M.Y. M. Razif

ORCID: 0000-0002-8563-9000

Universiti Kebangsaan Malaysia

Medical Centre, Department of Otorhinolaryngology,

Kuala Lumpur, Malaysia

K.A.S.A. Dahari

ORCID: 0000-0002-2318-2199

Seremban General Hospital,

Department of Otorhinolaryngology,

Seremban, Malaysia

A.M. Tamil

ORCID: 0000-0002-1657-3351

Universiti Kebangsaan Malaysia,

Faculty of Medicine, Department

of Public Health, Kuala Lumpur, Malaysia

J. Rohana

ORCID: 0000-0003-2329-5123

I. Shareena

ORCID: 0000-0003-4964-773X Universiti Kebangsaan Malaysia, Faculty of Medicine, Department of Pediatric, Kuala Lumpur, Malaysia

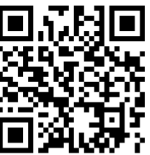




\section{INTRODUCTION}

It is estimated that 466 million people have disabling hearing loss $(\mathrm{HL})$, and 34 million of them are children. Statistics shows that by the year 2050, about 900 million people will have this condition. According to the definition by WHO, disabling HL refers to hearing loss greater than $40 \mathrm{~dB}$ in the better hearing ear in adults and greater than $30 \mathrm{~dB}$ in the better hearing ear in children ${ }^{1}$. Early detection of congenital hearing loss is of vital importance as delayed detection has a negative impact on language, cognition, education and social development of an affected child.

Congenital $\mathrm{HL}$ is among the most common major disabilities present at birth. It includes hereditary $\mathrm{HL}$ and $\mathrm{HL}$ due to other factors present either in-utero or at the time of birth. The prevalence of $\mathrm{HL}$ has been reported as 1-3 per 1000 live births and is highest in South Asia, Asia Pacific and the Sub-Saharan Africa region ${ }^{1,2}$. Babies requiring intensive care in the Neonatal Intensive Care Unit (NICU) were reported to have a higher prevalence of $\mathrm{HL}$, involving up to $46 \%$ of newborns admitted to the $\mathrm{NICU}^{2}$. In 2018, Parab et al. ${ }^{3}$ reported a higher prevalence of $\mathrm{HL}$ amongst high risk babies, as 10.6 per 1000 high risk births compared to healthy neonates. A study in Malaysia in 2005 reported that $1 \%$ of high risk neonates in the NICU had $\mathrm{HL}^{4}$. A study by Pourarian et al. reported that $13.7 \%$ of newborns admitted to the $\mathrm{NICU}$ had $\mathrm{HL}^{2}$. In 2019, The Joint Committee on Infant Hearing $(\mathrm{JClH})$ stated that early detection of hearing loss, and intervention program should include surveillance and the intervention should be family centered ${ }^{5}$. This study aims to study the prevalence of $\mathrm{HL}$ in newborns and to identify the possible risk factors causing $\mathrm{HL}$.

\section{MATERIAL and METHODS}

This was a retrospective study conducted from January 2014 to December 2016 at University Kebangsaan Malaysia Medical Centre (UKMMC),
Kuala Lumpur, Malaysia. All newborns admitted to the NICU and had undergone hearing screening in the unit were included in the study. Our screening protocol was based on the modified protocol by The Joint Committee on Infant Hearing (JClH) (Figure 1). Every newborn admitted to the NICU underwent a 1 st stage hearing screening using OAE and AABR prior to discharge. The test either gave a "PASS" or "REFER" result which did not require interpretation. Newborns who failed the first stage screening test in NICU or with risk factors for HL underwent a diagnostic audiology test (2nd stage) in the Audiology Clinic in UKMMC at approximately 1-3 months of age. At this time the babies will have auditory brainstem response (ABR) test and tympanometry. Babies who missed the appointment for the first diagnostic test were given a re-appointment date. The result of the diagnostic test was recorded as either normal or abnormal. Data were analysed by using software SPSS version 20 to obtain the means, percentages and standard deviations.

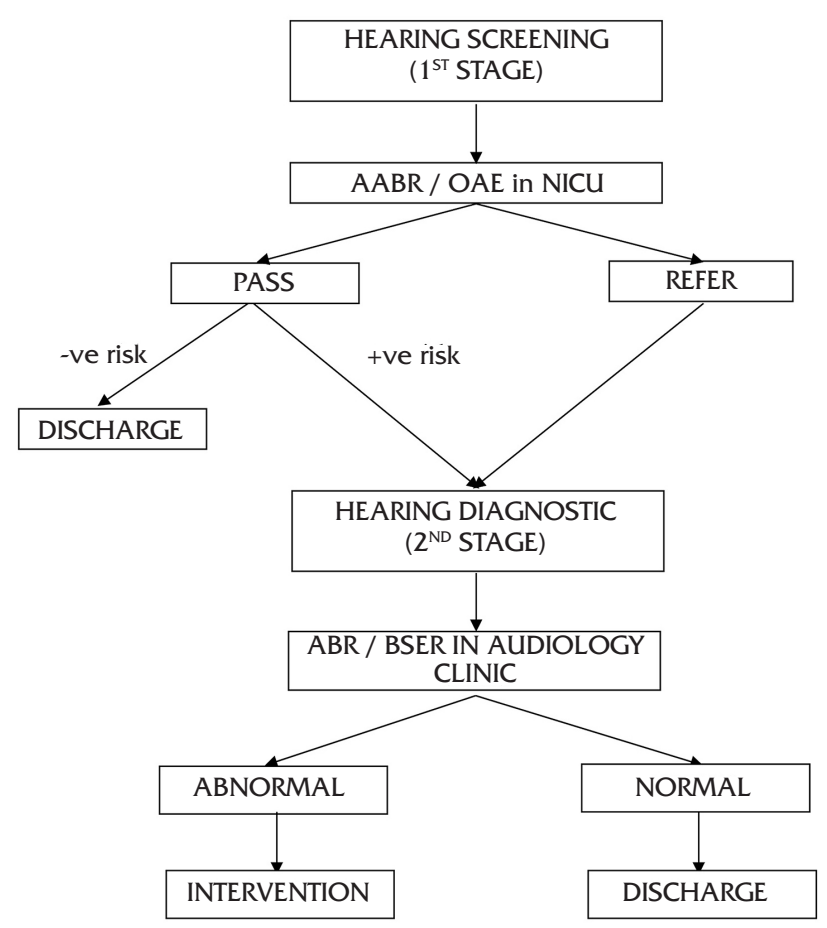

Figure 1. Protocol for hearing screening programme babies from NICU in UKMMC. 


\section{RESULTS}

A total of 2713 newborns admitted to the NICU UKMMC underwent 1 st stage hearing screening using OAE during the study period. Of these, 214 (7.9\%) required a 2 nd stage diagnostic testing for ABR. Only 105 (49\%) babies completed diagnostic tests. The majority (67.6\%) of them were male babies. The diagnostic test was performed at a mean age of 98 days. Forty (38.1\%) babies had HL. Twenty-nine of them (72.5\%) were males. The prevalence of $\mathrm{HL}$ among babies admitted to the NICU was $1.5 \%$ (40/2713). Out of 40 babies, 32 (80\%) had bilateral HL, 7 (17.5\%) had rightand 1 (2.5\%) left-sided HL. More than 50\% had mild HL. A summary of the degree of HL and the

Table 1. The distribution of hearing loss by severity in right and left ears.

\begin{tabular}{lll}
\hline Hearing level & Right ear, n (\%) & Left ear, n (\%) \\
\hline Mild & $23(59.0)$ & $16(51.6)$ \\
Moderate & $9(23.1)$ & $6(19.4)$ \\
Severe & $3(7.7)$ & $3(9.6)$ \\
Profound & $4(10.2)$ & $6(19.4)$ \\
& & \\
\hline
\end{tabular}

Table 2. Risk factors associated with HL $(\mathbf{N}=105)$.

\begin{tabular}{|c|c|c|c|}
\hline Risk Factor & $\begin{array}{l}\text { Babies, } \\
\text { n (\%) }\end{array}$ & $\begin{array}{l}\text { Hearing loss, } \\
\text { n (\%) }\end{array}$ & $\begin{array}{l}\mathbf{p} \\
\text { value }\end{array}$ \\
\hline $\begin{array}{l}\text { Low Apgar Score } \\
(<6 \text { at } 5 \mathrm{~min})\end{array}$ & $15(14.3)$ & $6(5.7)$ & 0.87 \\
\hline $\begin{array}{l}\text { Hyperbilirubinemia } \\
(>300 \mu \mathrm{mol} / \mathrm{L})\end{array}$ & 23 (21.9) & $9(8.6)$ & 0.908 \\
\hline Low birth weight $(<1500 \mathrm{~g})$ & $17(16.2)$ & $5(4.8)$ & 0.421 \\
\hline Ventilated $>5$ days & $9(8.6)$ & $5(4.8)$ & 0.259 \\
\hline Craniofacial anomalies & $17(16.2)$ & $13(12.4)$ & 0.000 \\
\hline Ototoxic drug & $11(10.5)$ & $4(3.8)$ & 0.901 \\
\hline
\end{tabular}

Table 3. Risk factor and logistic regression.

\begin{tabular}{lll}
\hline Risk factors & P Value & Odds Ratio [95\% Cl] \\
\hline $\begin{array}{l}\text { Low Apgar Score } \\
\text { (<6 in 5 minutes) }\end{array}$ & .130 & $3.203[0.709-14.474]$ \\
Low Birth Weight $(<1.5 \mathrm{~kg})$ & .564 & $0.657[0.158-2.737]$ \\
$\begin{array}{l}\text { Hyperbilirubinaemia } \\
\text { (>300 mmol/L) }\end{array}$ & .125 & $2.402[0.785-7.356]$ \\
$\begin{array}{l}\text { Ototoxic drug } \\
\text { Ventilated }>5 \text { days }\end{array}$ & .885 & $1.119[0.242-5.167]$ \\
Craniofacial anomalies & .159 & $3.351[0.623-18.032]$ \\
\hline
\end{tabular}

risk factors of HL are listed in Table 1 and 2 . None of our babies has auditory neuropathy.

Logistic regression test showed an association between craniofacial anomalies and HL. There was an increased risk of HL in ototoxic drug usage by 1.12 and with low Apgar score, the risk was 1.7 of having HL. (Table 3 ).

Table 4 shows lack of any association between the presence of risk factors and HL. Babies with a risk factor of $\leq 1$ for hearing loss have $36.0 \%$ chance of having $\mathrm{HL}$ and babies with $\geq 2$ risk factors have a $47.4 \%$ chance of having HL. However there was no significant statistical difference $(p=0.378)$ between the presence of risk factors and developing hearing loss.

Table 4. Comparison presence of risk factor and of hearing loss $(n=105)$.

\begin{tabular}{lll}
\hline \multirow{2}{*}{ Risk } & \multicolumn{2}{c}{ Hearing Loss } \\
\cline { 2 - 3 } & Yes, n (\%) & No, n (\%) \\
\hline No Risk $(\mathrm{n}=37)$ & $11(29.7)$ & $26(70.3)$ \\
1 Risk $(\mathrm{n}=49)$ & $20(40.8)$ & $29(59.2)$ \\
2 Risks or more $(\mathrm{n}=19)$ & $9(47.4)$ & $10(52.6)$ \\
Total & $40(38.1)$ & $65(61.9)$ \\
\hline
\end{tabular}

\section{DISCUSSION}

The present study was conducted as part of the evaluation of the UNHS program in UKMMC. The UNHS program is the current standard of practice in most countries and is aimed at detecting $\mathrm{HL}$ amongst children at a very early age. The critical period hypothesis $(\mathrm{CPH})$ states that the first few years of life constitute the time during which language and speech develops readily and after which language acquisition becomes much more difficult and ultimately less successful. Yoshinaga-Itano et al. $^{6}$ reported that the children whose hearing losses were identified by 6 months of age and received an early intervention have demonstrated significantly better receptive and expressive language abilities. 
According to the $\mathrm{JClH}$, hearing impairment should ideally be detected by the age of 3 months and intervention be started by 6 months. Our study has showed that the mean age at the time of diagnostic test was 3 months and 8 days. Though we were able to make an early diagnosis of hearing loss, a large number of babies were missed due to the high default rate. Our previous studies showed a return follow-up rates ranging between $57 \%$ and $65 \%^{7,8}$.

We found that the prevalence of $\mathrm{HL}$ for babies admitted to the NICU was $1.5 \%$ which is comparable with the results of the study done by Khairi et al. ${ }^{4}$. However, our prevalence was lower compared to other studies ${ }^{3,9}$. The low prevalence may be explained by the low number of babies (49\%) who had completed the diagnostic test.

Mild HL was the most common form of HL found in this study. This is in contrast with the findings of a study by Abu-Shaheen at al. which demonstrated that most neonates with HL developed severe to profound HL. Their study showed that mild HL was seen in $18.9 \%$, moderate $\mathrm{HL}$ in $33.1 \%$, severe $\mathrm{HL}$ in $20.2 \%$ and profound $\mathrm{HL}$ in $27.8 \%$ of newborns ${ }^{10}$. The language and speech skills of children with mild HL often develop normally. However, as they usually would not be able to understand conversations clearly, they may perform poorer academically achievement compared to their normal hearing peers.

The presence of craniofacial anomalies was the only independent significant risk factor associated with HL. There was an increased risk of hearing loss in those with craniofacial anomalies up to 11 times higher compared to those without such anomalies. HL was diagnosed in babies with cleft lip and palate, trisomy 21 and Pierre Robin syndrome. Other risk factors studied did not significantly contribute to $\mathrm{HL}$. Our result was similar with other studies ${ }^{4,9}$.

Ototoxic drug usage has been identified as a risk factor for HL in babies. Aminoglycosides and loop diuretics can damage the cochleovestibular system leading to irreversible destruction of outer hair cells in the organ of Corti and stria vascularis, respectively. From our study, ototoxic drugs did not seem to be an important factor contributing to the increased risk for HL. Robertson et al. reported that overuse of loop diuretics contributes to $\mathrm{HL}^{11}$. Loop diuretics are used judiciously in our centre and the serum level of aminoglycosides is monitored regularly and its use rarely exceeds 5 days.

Babies requiring mechanical ventilation for more than 5 days have a higher risk of HL. This fact is supported by the findings from a study conducted by Bielecki et al which reported that the second highest incidence of HL (11.45\%) occurred in infants subjected to mechanical ventilation for a period in excess of 5 days. This may be due to hypoxia especially if it is recurrent or prolonged and particularly if it occurs in combination with ischemia ${ }^{12}$. Interestingly, a study by Maqbool et al. ${ }^{13}$ reported that $\mathrm{HL}$ associated with mechanical ventilation could be transient due to the presence of middle ear effusion seen in ventilated babies. However, in our study, mechanical ventilation was not a significant independent risk factor.

Our study found that hyperbilirubinaemia was the most common risk factor identified in the babies screened for HL. HL was detected in all babies (100\%) that had undergone exchange transfusion and in $39.1 \%$ with severe hyperbilirubinaemia. Bilirubin, at high levels, can damage retrocochlear structures such as the brainstem auditory nuclei, inferior colliculi, spiral ganglion neurons, and auditory nerve fibres, with greater dysfunction noted at higher total serum bilirubin levels ${ }^{14}$. Local studies by Boo et al. ${ }^{15}$ showed a HL prevalence of $12.8 \%$ among babies with severe hyperbilirubinaemia.

Our study also showed that among babies without any apparent risk factor, the prevalence of $\mathrm{HL}$ is 
$29.7 \%$. The prevalence increased as the number of risk factors present increased however there was no significant statistical association * $(p=0.378)$ between the presence of risk factors and developing hearing loss. A study by Maqbool et al. ${ }^{13}$ showed an increasing prevalence of abnormal ABR with the presence of increasing numbers of risk factors in babies. Indeed, the presence of one, two and three risk factors increased the prevalence rate of HL by $4.28 \%, 22.2 \%$ and $33.3 \%$, respectively.

\section{LIMITATION}

There was a high default rate for diagnostic test appointment which reduced the pick-up rate of diagnosing HL. Data tracking tympanometry results was not included in this study and therefore, we cannot comment on the type of HL. Further studies with a higher follow up rate and with tympanometry results are required to highlight the importance of hearing assessment in high-risk newborns.

\section{REFERENCES}

1. World Health Organization. WHO statement on hearing loss prevalence accessed on March 1, 2020. Available from: https://www.who.int

2. Pourarian S, Khademi B, Pishva N, Jamali A. Prevalence of hearing loss in newborns admitted to neonatal intensive care unit. Iran J Otorhinolaryngol. 2012;24:129-34.

3. Parab SR, Khan MM, Kulkarni S, Ghaisas V, Kulkarni P. Neonatal Screening for Prevalence of Hearing Impairment in Rural Areas. Indian Journal of Otolaryngol Head Neck Surg. 2018;70:380-6. [CrossRef]

4. Khairi MDM, Din S, Shahid H, Normastura AR. Hearing screening of infants in Neonatal Unit, Hospital Universiti
Sains Malaysia using transient evoked otoacoustic emissions. J Laryngol Otol. 2005;119:678-83. [CrossRef]

5. Year 2019 Position Statement: Principles and Guidelines for Early Hearing Detection and Intervention Programs. Journal of Early Hearing Detection and Intervention. 2019;4(2):1-44.

6. Yoshinaga-Itano C, Sedey AL, Coulter DK, Mehl AL. Language of early-and later-identified children with hearing loss. Pediatrics. 1998;102:1161-71. [CrossRef]

7. Mukari SZ, Tan KY, Abdullah A. A pilot Project on hospital-based universal newborn hearing screening: Lessons learned. International Journal of Pediatric Otorhinolaryngology. 2006;70:843-51. [CrossRef]

8. Abdullah A, Hazim MY, Almyzan A, et al. Newborn Hearing Screening: Experience in a Malaysian Hospital. Singapore Med J. 2006; 47:60-4.

9. Salvago P, Martines E, Martines F. Prevalence and risk factors for sensorineural hearing loss: Western Sicily overview. Eur Arch Otorhinolaryngol. 2013;270:3049-56. [CrossRef]

10. Abu-Shaheen A, Al-Masri M, El-Bakri N, Batieha A, Nofal A, Abdelmoety D. Prevalence and risk factors of hearing loss among infants in Jordan: Initial results from universal neonatal screening. Int J Audiol. 2014;53:91520. [CrossRef]

11. Robertson CMT, Juzer MT, Peliowski A, Philip CE, Cheung P-Y. Ototoxic drugs and sensorineural hearing loss following severe neonatal respiratory failure. Acta Paediatrica. 2006;95:214-23. [CrossRef]

12. Bielecki I1, Horbulewicz A, Wolan T. Risk factors associated with hearing loss in infants: an analysis of 5282 referred neonates. Int J Paediatr Otorhinolaryngol. 2011;75:925-30. [CrossRef]

13. Maqbool M, Najar BA, Gattoo I, Chowdhary J. Screening for Hearing Impairment in High Risk Neonates: A Hospital Based Study. J. Clin. Diagnostic Res. 2015;9:SC18. [CrossRef]

14. Wickremasinghe AC, Risley RJ, Kuzniewicz MW, et al. Risk of Sensorineural Hearing Loss and Bilirubin Exchange Transfusion Thresholds. Pediatrics. 2015;136:505-12. [CrossRef]

15. Boo NY, Rohani AJ, Asma A. Detection of sensorineural hearing loss using automated auditory brainstem-evoked response and transient-evoked otoacoustic emission in term neonates with severe hyperbilirubinaemia. Singapore Med J. 2008;49:209-14. 